\title{
Understanding Agricultural Liability: Premise's Liability
}

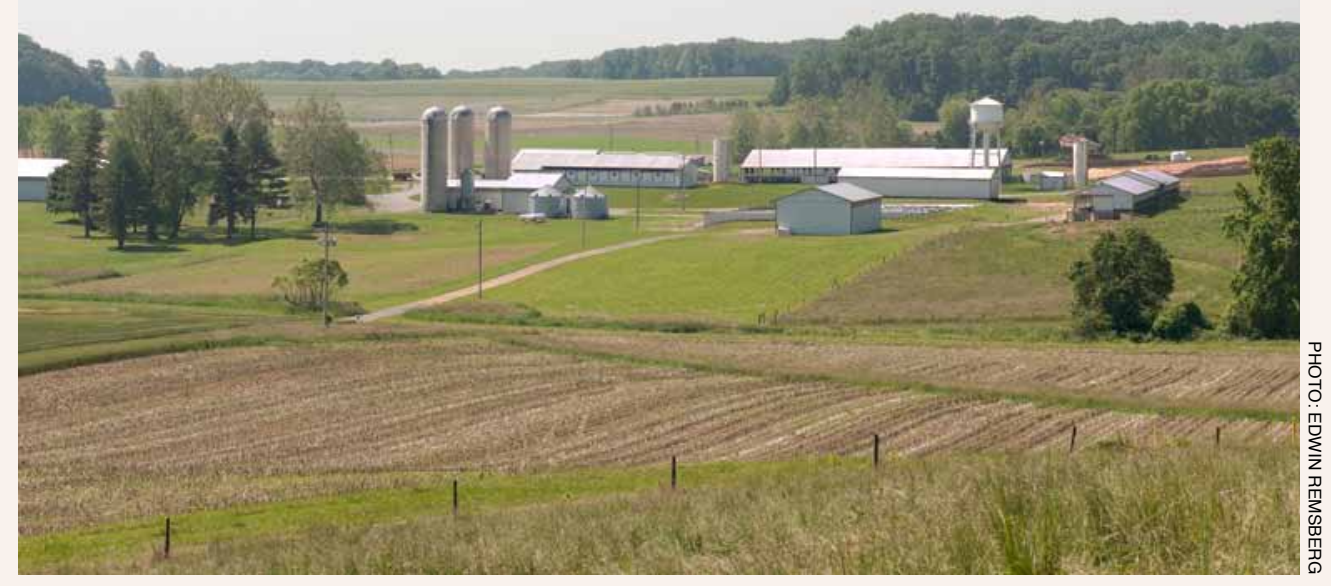

Steps you can take to limit your liability on the farm include obtaining insurance, procuring releases, and providing warnings.

Y ou face many risks in your farming operation, including weather, crop prices, and environmental issues beyond your control. If you own or lease farmland, you also may encounter the liability risks associated with individuals coming on to your land, whether invited or not.

You can take steps to limit your potential liability by understanding your legal obligation or duty to protect visitors and other third parties from foreseeable harm. You also will need to know to whom you owe the duty and what duty others may owe to you. Steps you can take to limit your liability include obtaining insurance, procuring releases, and providing warnings. You should work with a licensed attorney in your area and your insurance agent to identify the tools that will work best for you.

Regardless of the steps taken, however, you cannot eliminate 100 percent of your liability, but you can reduce your exposure to some existing liability and limit potential costs.

\section{Duty of Care Owed to Visitor}

Depends on Classification as Trespasser, Licensee, or Invitee

Duty of care, in the case of visitors to a property, is simply the legal obligation the owner or lessee owes to visitors to protect them from foreseeable harm. The duty of care depends on the reason that the visitor is on the property.

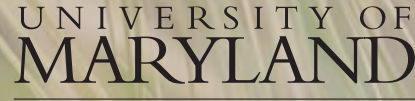

E X T E N S I O N 


\section{Trespassing Can Be Criminal or Civil}

A trespasser is a person who enters your farmland without your consent and remains without your consent (Rivas, 2000). For example, Charlie is hunting on your neighbor's property, inadvertently gets onto your farm, and continues to hunt on your property. Charlie would be a trespasser in this case because he entered your property and remained there without your consent. Charlie may have committed one of two types of trespass recognized in Maryland: 1) criminal trespass and 2) civil trespass.

\section{Criminal Trespass}

The Maryland Criminal Law Code defines criminal trespass and identifies four situations when it takes place:

1) A property is clearly posted with "No Trespassing" signs which can be reasonably seen (MD. CRIM. LAW Code AnN. § 6-402(a)(1)). Department of Natural Resources regulations also allow for a paint mark on trees indicating no trespassing (MD. NAT. Res. Code ANN. § 6-402(a)(2)).

2) A person who pulls a vehicle, including a farm tractor or lawnmower, onto a private driveway clearly marked as private (MD. CRIM. LAW CODE AnN. § 6-404). There is no requirement on the exact wording of the sign, but it must warn against trespassing (Monroe, 1981).

3) A trespasser returns to or remains on private property after being warned by the owner or tenant to leave (Md. CRim. Law Code AnN. § 6-403(a) to (b)).

4) A person who, without the owner's or tenant's permission, enters cultivated land, i.e. property cleared of its natural vegetation and planted with a crop or orchard (MD. CRIM. LAW Code AnN. § 6-406).

Maryland law states that anyone guilty of criminal trespass is subject to imprisonment of no more than 90 days or a fine not to exceed $\$ 500$. For information on how many No Trespassing signs to hang, see Frequently Asked Questions: Hanging No Trespassing Signs, 2014.

\section{Civil Trespass}

Trespass is also a tort, or civil wrong, to the owner or tenant of the property. To show trespass, the owner or tenant must prove that the:

1) Other person occupied or exercised some control over your property;

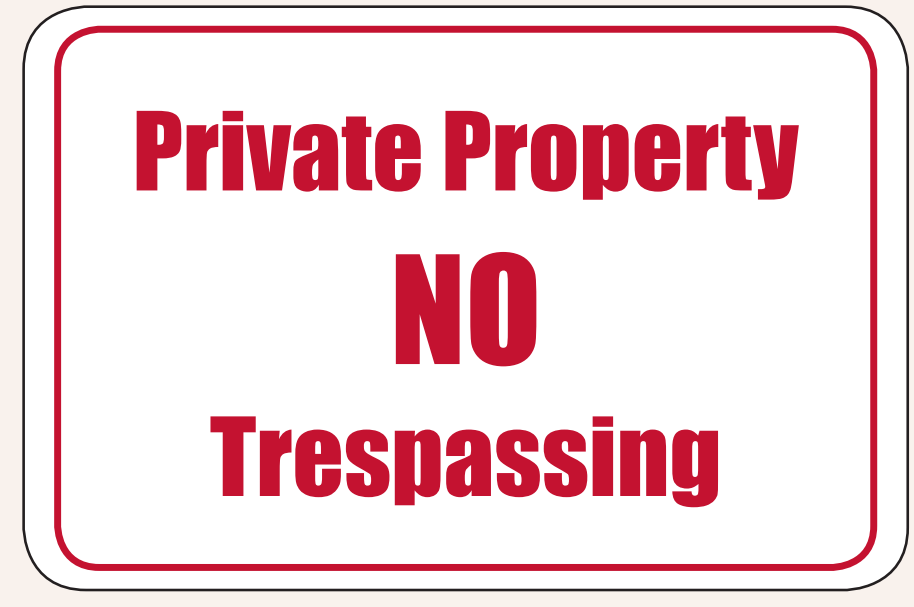

Maryland law states that anyone guilty of criminal trespass is subject to imprisonment of no more than $\mathbf{9 0}$ days or a fine not to exceed $\$ 500$.

2) Control or occupation of your property occurred because of the other party's physical act or force against the property; and

3) Other party did not have your permission to be on the property (Mitchell, 2005).

When a person trespasses, you would be able to sue the other party for damages to your property and you could also sue to have the person enjoined from committing further trespass. For example, if a neighbor occupies your crop field by riding an ATV through it without your permission and tears up a portion of your corn crop, the neighbor has trespassed. If your neighbor is unwilling to pay for damages, you have the option to file a civil suit for trespass seeking damages for the ruined corn against the neighbor. You also may have the option to press criminal trespassing charges against the neighbor. ${ }^{2}$

According to the Maryland courts, the duty of care owners or tenants owe a trespasser is to refrain from wanton or willful injury (Rivas, 2000). Willful means it was "performed with the actor's actual knowledge or with what the law deems the equivalent to actual knowledge of the peril to be apprehended, coupled with a conscious failure to avert injury" (Wells, 1998). Wanton is "conduct that is extremely dangerous and outrageous, in reckless disregard for the rights of others" (Wells, 1998). Conduct that rises to the level of willful or wanton will depend on the facts in each case.

For example, you know that ATV riders repeatedly cross part of your property to access a public trail. 
To stop this, you string an unmarked cable across the trail on your property. An ATV rider unaware of the unmarked cable rides into it and is injured. This could be an example of a willful and wanton injury and a breach of the duty of care you owe a trespasser. If in the same example, you constructed a clearly visible fence in the same location and the ATV rider ran into the fence and was injured, you would likely not be found liable to the rider for injuries; however, the rider would be liable to you for the cost of repairing your fence.

\section{Maryland Courts Recognize Two Types of Licensees: Bare Licensee and Licensee by Invitation}

A bare licensee has permission to be on the property, but is there for his/her own purpose. For example, you allow a neighbor to hunt on your property (Rivas, 2000). According to Maryland court decisions, you have a similar duty as with a trespasser to refrain from willful or wanton injury from creating new and undisclosed sources of danger without warning (Rivas, 2000). This would mean simply providing a warning of any known dangers on the property, such as sinkholes, cables across paths, or other known hazardous conditions. If a dog kept on the property has bitten someone in the past, a "Beware of Dog" sign by the property's entrances would alert licensees to the dog's presence (for more information on "Beware of Dog" signs, please see Goeringer, 2014).

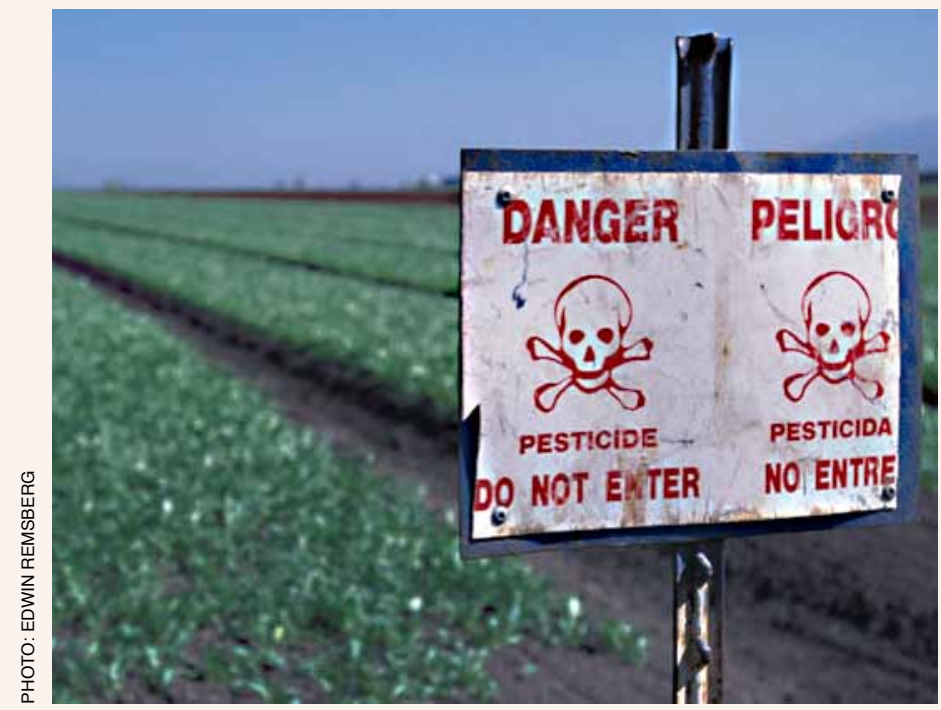

According to Maryland court decisions, you have a similar duty as with a trespasser to refrain from willful injury from new and undisclosed sources of danger without warning, which would mean providing a warning of any known dangers on the property.
Similar warnings could be posted for other animals on the property that have injured others, such as a bull or horse.

A licensee by invitation is a person you invite on your property, such as a party guest (Rivas, 2000). Your duty is to fix known problems or warn the licensee about dangerous conditions which are not easily discoverable (Rivas, 2000). There is no requirement to discover every possible danger, just to warn about those known to you.

A bare licensee or a licensee by invitation can become a trespasser if the licensee uses more of the property than you originally allowed. For example, you grant your neighbor access to a small pond on your property. While using the pond, the neighbor sees an old barn on the property and walks over to explore it. Once the neighbor extends his use beyond the pond by walking to the barn, he has become a trespasser.

\section{An Invitee Is a Person Invited Onto Your Property for Your Economic Benefit}

If you operate a business which invites customers onto your property, for example, your customers are invitees. Invitees are owed the highest duty of care. Your duty is to protect them from unreasonable risks and keep the property reasonably safe (Rivas, 2000). You should inspect the property for dangerous conditions, warn of these hazards, and possibly remedy these unsafe situations.

For example, you sell homemade ice cream on site made from milk produced on your farm. To get into the creamery, customers must walk up three wooden steps and you notice that the top step is starting to rot. In order to meet your duty of care to invitees, you should repair the wooden step within a reasonable time of discovering it is rotten. Until it is fixed, you should provide some warning, such as a sign stating "Be Careful of the Rotten Step," and direct your customers to an alternative route into the creamery (such as a handicap ramp) until the step is fixed.

An invitee who goes beyond areas normally allowed becomes a trespasser. For example, you sell produce on your farm out of a small building. While in the building, the customer is an invitee to whom you owe the highest duty of care. If the customer purchases a large quantity of produce which requires driving around to a loading area, the customer would become a licensee with permission to enter an area not normally used by customers. The customer would become a trespasser if he/she enters areas of the building clearly marked 


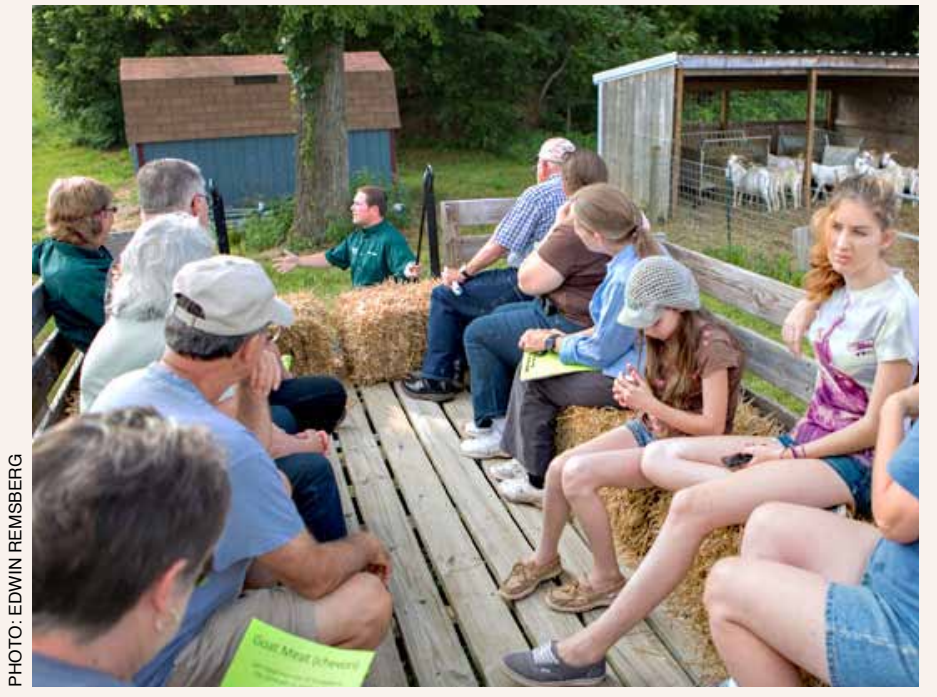

To gain Recreational Use Statute protections, a landowner/ tenant must allow the guests on the property for an educational pursuit or "any recreational purpose."

"Employees Only." If injured while in such an area, the customer would have to show that the injury was caused by your willful or wanton conduct in failing to warn of the risk. The duty of care owed to a customer depends on where he/she was on your premises at the time of injury and what kind of access customers are typically granted to that location.

\section{Maryland Statute Encourages Access to Properties for Recreational Use by Lowering Standard of Care Owed Visitors}

The Recreational Use Statute (RUS) is designed to encourage landowners/tenants to make land available to recreational users. The statute imposes no duty of care on the owner to keep premises safe or provide warnings to any recreational or educational user of the property. Rather, under the RUS, the duty of care owed to a recreational or educational user is the same as that owed to a trespasser and a landowner/tenant; that is, to refrain from willful or malicious failure to guard against dangerous conditions on the property.

In order to gain the RUS protections, a landowner/ tenant must allow the guests on the property for an educational pursuit or "any recreational purpose" (Nat. Res. § 5-1101(f)). For example, allowing a friend to use your property to ride his/her horse or for a hike would be considered recreational uses. The statute is broad to encompass as many recreational uses as possible.
An educational use would include "(1) Nature study; (2) Farm visitations for purposes of learning about the farming operation; (3) Practice judging of livestock, dairy cattle, poultry, other animals, agronomy crops, horticultural crops, or other farm products; (4) Organized visits to farms by school children, 4-H clubs, FFA clubs, and others as part of their educational programs; (5) Organized visits for purposes of participating in or observing historical reenactments as part of an educational or cultural program; and (6) Observation of historical, archaeological, or scientific sites." (Nat. Res. $\S 5$-1101(c)(1)-(6)). An example of an educational use is when other farmers visit Sally's farm to learn about certain practices she uses. If Sally invites area school kids on her farm as part of a field trip, this also would be considered an educational use.

To be within the scope of the RUS statute, a landowner/tenant must allow the recreational or educational user access to the property for no charge. The law defines charge to mean "price or fee asked for services, entertainment, recreation performed, products offered for sale on land or in return for invitation or permission to enter or go upon land." (Nat. Res. $\S$ 5-1101(b)(1)). Courts in other states have found that "charge" does not include fees paid to park a vehicle, camper, etc., as long as the fee is unrelated to the admission of people using the property for recreational purposes. Farmers also should refrain from offering products for sale on the land in order to retain the protections of the RUS law.

The definition of charge, however, does contain three exemptions:

1) Recreational users can share with the landowner/ tenant any game, fish, or other products from the recreational use (Nat. Res. § 5-1101(b)(2)(i)). For example, a nephew is allowed to hunt on Steve's property. In return for access to the property, the nephew often gives Steve some of the meat from wildlife killed on the property. This would not be considered a "charge."

2) Benefits "to the land arising from the recreational use" (such as increased property values) also are not considered charges under the RUS. (Nat. Res. $\S 5-1101(\mathrm{~b})(2)(\mathrm{ii}))$. For example, deer have been destroying your corn crop and you allow hunters to come on your property. The deer hunters are successful and the deer do not further damage your 
corn crop. This benefit to your land--fewer deer to damage your crops--would not be considered a "charge" under the statutory definition.

3) "[C]ontributions in kind or services to promote the management or conservation of the land" (Nat. Res. § 5-1101(b)(2)(iii)) also are exempt from the definition of "charge." A landowner/tenant is allowed to collect contributions that go to the sound management of the property's natural resources. For example, a forest management specialist enjoys using Mary's property for hunting and fishing. In return for access, the specialist provides Mary with expert advice on how to better manage the property. This service provided would be excluded from the statutory definition of "charge."

Agritourism operators, wineries, and any other producers selling farm products to consumers are not likely to be within the scope of the RUS law because the definition of "charge" is met by collection of fees for admission or rides, or payment for produce, etc. Visitors to these operations are considered invitees and would need to be protected from unreasonable dangers. For example, the operators of a corn maze typically charge an admission or other fee to use the corn maze. A winery would be excluded from the RUS law's protections because the operator offers wine and other products for sale on the property.

\section{Farm Risk Cannot Be Eliminated But Can Be Managed}

Landowners/tenants considering allowing the public on their property for recreational uses, an agritourism operation, or an on-farm business, should start by walking the areas users will access to determine potential risks. Next, determine ways to lessen some of those potential risks. Do you need to fill in a hole or rope off certain areas and hang signs warning third parties of potential dangers? This initial review will not eliminate all risks, but will help you determine and limit some of the risks on your property and the areas you are willing to allow third parties to use.

You should consider purchasing some form of a comprehensive liability insurance policy. Many farmers already have a general comprehensive liability policy for their agricultural operations which offer a good way to manage liability risks by shifting a portion of it to the insurance company. But comprehensive liability insurance is just one way to limit risk in your operation.

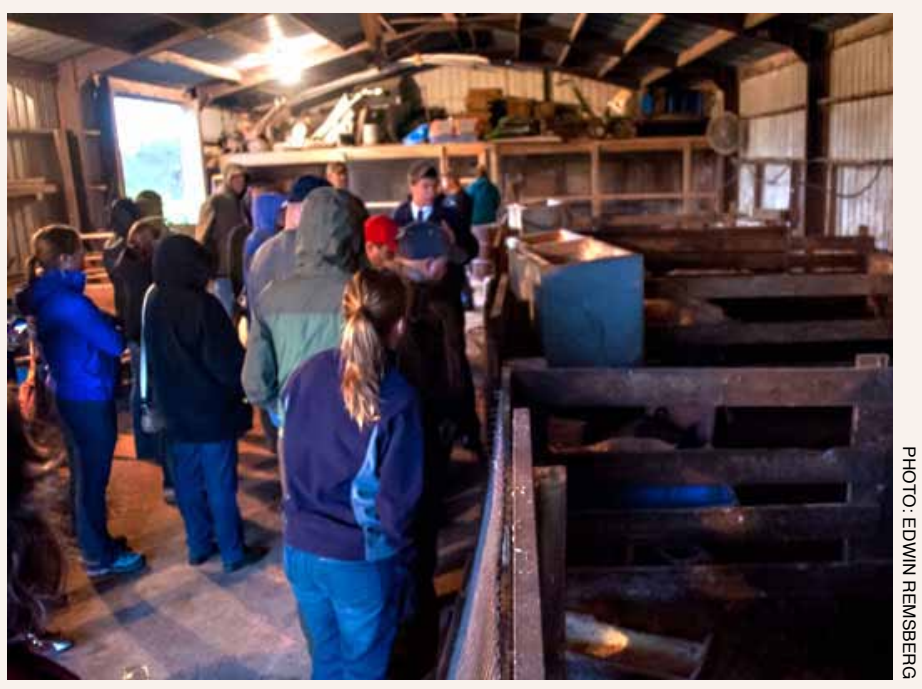

Talk with your local insurance agent to help you select the best comprehensive liability insurance coverage for your operation.

Other business operations, such as creameries, wine tasting rooms, agritourism ventures, etc., typically are excluded from a traditional comprehensive farm liability policy because these enterprises are not viewed as a part of the farming operation. Farmers with these types of diversified operations should talk with a local insurance agent to purchase an additional policy for operations ineligible for traditional comprehensive liability insurance. The type of coverage needed will depend on a host of factors and an insurance agent will be able to help these farmers pick coverage levels which fit their needs.

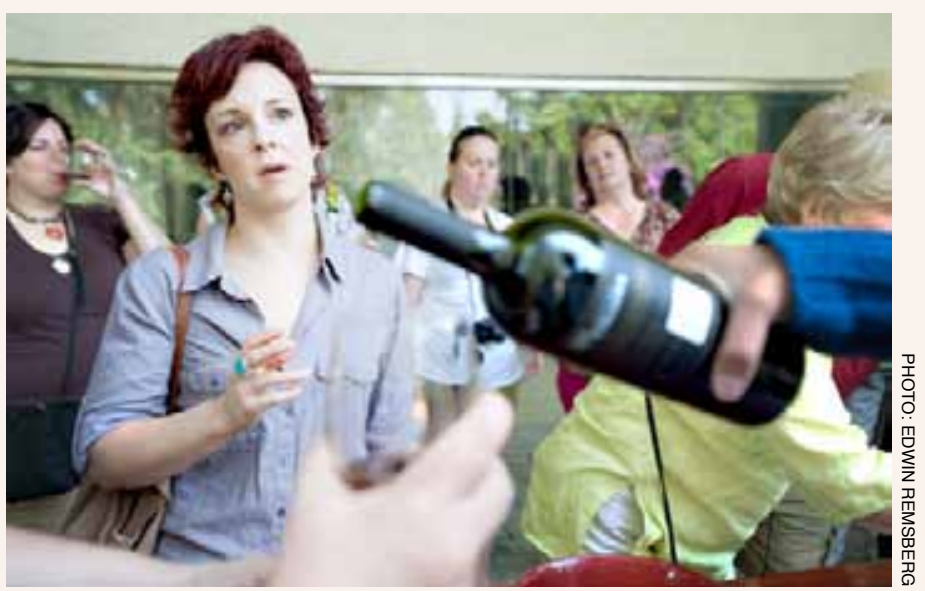

Business operations, such as creameries, wine tasting rooms, and agritourism ventures typically are excluded from a traditional comprehensive farm liability policy because these enterprises are not viewed as a part of the farming operation. 
Finally, consult your lawyer. Often times, risks may be avoided by having the visitor sign a well-crafted release waiving liability in the event of accident or injury. For more information on liability waivers, see Newhall, 2014.

\section{References}

Becker, John C., Lynn F. Klime, Jayson K. Harper, and Ross Pifer. Understanding Agricultural Liability. Small-scale and Part-time Farming Project at Penn State University.

Copeland, J.D. 1992. "The Farmer's Comprehensive Liability Policy: The Business of Pursuits Exclusion." Arkansas Lawyer, April, pp. 44-46.

Goeringer, Paul. 2014. "Frequently Asked Questions: Hanging No Trespassing Signs." Maryland Risk Management Education Blog, Sept. 25. Internet site: www.aglaw.umd.edu/blog/ frequently-asked-questionshanging-no-trespassing-signs.

Goeringer, Paul. 2014. "Is Hanging a 'Beware of Dog' Sign a Good Idea?" Maryland Risk Management Education Blog, May 19. Internet site: www.aglaw.umd.edu/blog/beware-of-dog-sign.

Looney, J.W., and D.L. Uchtmann. 1994. Agricultural Law: Principles and Cases. New York: McGraw-Hill, Inc.

Md Code Ann. Crim. LaW $\S \S 6-402$ to 6-403 (West 2013).

Md Code Ann. Nat. Res. §§ 5-1101 to 5-1109 (West 2013).

Mitchell v. Baltimore Sun Co., 883 A.2d 1108 (Md. Ct. Spec. App. 2005).

Monroe v. State, 445 A.2 1047 (Md. Ct. Spec. App. 1982).

Newhall, A. 2014. "Liability Waiver-Something You Should Consider To Protect Your Farm." Maryland Risk Management Education Blog, Oct. 30. Internet site: www.aglaw.umd.edu/blog/liability-waiver-somethingyou-should-consider-to-protect-your-farm.

Noble, M.L. 1990-91. "Recreational Access to Agricultural Land: Insurance Issues." Indiana Law Review 24: 1615-40.

Pifer, Ross H. 2010. "Understanding Negligence Liability Against Rural Landowners.” PGP Magazine, July, pp 21.

Rivas v. Oxon Hill Joint Venture, 744 A.2d 1076 (Md. Ct. Spec. App. 2000). Wells v. Polland, 708 A.2d 34 (Md. Ct. Spec. App. 1998).

Note: This publication is intended to provide general information about legal issues in premises liability and should not be construed as providing legal advice. It should not be cited or relied upon as legal authority. State laws vary and no attempt is made to discuss laws of states other than Maryland. For advice about how the issues discussed here might apply to your individual situation, you should consult an attorney. 
${ }^{1}$ If a paint mark is used then it must "be placed at each road entrance and adjacent to public roadways, public waterways, and any other lands adjoining the property. For purposes of this regulation, a paint mark shall be:

(a) A vertical line at least 2 inches in width, and at least 8 inches in length,

(b) Centered at least 3 feet, but not more than 6 feet from the ground, or from the water surface at its mean high tide for tidal water, or its normal level for nontidal water,

(c) Readily visible to a person with normal eyesight who approaches the property, and

(d) Bright blue oil base paint." (Md. Code Regs. 08.01.05.01)

${ }^{2}$ Always talk with an attorney in your area about the specific facts of your situation to determine your options when you believe a trespass has taken place.

The Agriculture Law Education Initiative is a collaboration between the University of Maryland Francis King Carey School of Law and College of Agriculture \& Natural Resources, University of Maryland, College Park. Through the University of Maryland Extension - the statewide, non-formal agriculture education system - the collaboration partners with the School of Agricultural and Natural Sciences, University of Maryland Eastern Shore.

The University of Maryland: MPowering the State brings together two universities of distinction to form a new collaborative partnership. Harnessing the resources of each, the University of Maryland, College Park and the University of Maryland, Baltimore will focus the collective expertise on critical statewide issues of public health, biomedical informatics, and bioengineering. This collaboration will drive an even greater impact on the state, its economy, the job market, and the next generation of innovators. The joint initiatives will have a profound effect on productivity, the economy, and the very fabric of higher education.

http://www.mpowermaryland.com
Authored by:

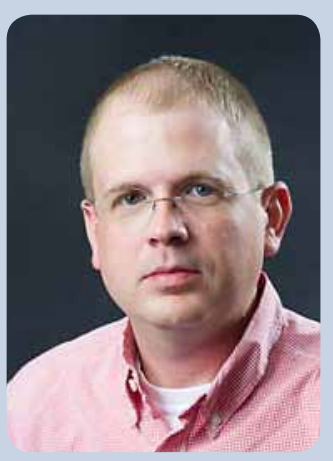

Paul Goeringer Extension Legal Specialist lgoering@umd.edu @aglawPaul

University of Maryland College of Agriculture and Natural Resources

Department of Agricultural and Resource Economics

Symons Hall, Room 2119 College Park, MD 20742

www.umaglaw.org

Twitter @MDAgLaw

(301) 405-1293 